\title{
Beta-lactamases of type culture strains of the Bacteroides fragilis group and of strains that hydrolyse cefoxitin, latamoxef and imipenem
}

\section{A. ELEY and D. GREENWOOD \\ Department of Microbiology and Public Health Laboratory, University Hospital, Queen's Medical Centre, Nottingham NG7 2UH}

\begin{abstract}
Summary. Susceptibilities to $\beta$-lactam antibiotics and $\beta$-lactamase content of two groups of Bacteroides strains were compared. Type cultures produced low levels of $\beta$ lactamase and were susceptible to cefoxitin, latamoxef, imipenem and the combination of benzylpenicillin and clavulanic acid. Other Bacteroides strains that produced higher levels of $\beta$-lactamase were generally less susceptible to these antibiotics; this resistance was more closely related to enzyme type than to the amount of enzyme present.

The $\beta$-lactamases produced by the test strains fell into three broad groups on the basis of antibiotic degradation and inhibitor profiles: (i) those that inactivated benzylpenicillin, but not cefoxitin, latamoxef or imipenem, and were susceptible to inhibition by $\beta$-lactamase inhibitors; (ii) those that hydrolysed benzylpenicillin, cefoxitin and latamoxef, but not imipenem, and which were less susceptible to inhibition by $\beta$-lactamase inhibitors; (iii) an enzyme that inactivated all the antibiotics and was not inhibited by $\beta$-lactamase inhibitors.
\end{abstract}

\section{Introduction}

Production of $\beta$-lactamase is the major factor involved in the resistance of many bacteria to $\beta$ lactam antibiotics and the Bacteroides fragilis group of organisms is no exception to this general finding. The resistance is highly dependent upon the level of $\beta$-lactamase activity and is not associated with any particular enzyme type (Simpson et al., 1982). There are at least four types of $\beta$-lactamase in the $B$. fragilis group. The most common type possessed by most strains has cephalosporinase activity (Anderson and Sykes, 1973); other enzymes have been described that inactivate cefoxitin (Cuchural et al., 1983) or imipenem (Yotsuji et al., 1983). A different enzyme, with penicillinase rather than cephalosporinase activity, has been described by Sato et al. (1982).

It has been suggested that the $\beta$-lactamases of Bacteroides spp. may be classified according to their substrate profiles and susceptibility to various enzyme inhibitors (Tajima et al., 1983) but such studies have generally been carried out on strains within the $B$. fragilis group that show normal susceptibility to $\beta$-lactam antibiotics.

We have selected for investigation type cultures of Bacteroides and strains able to inactivate cefoxi-

Received 18 Mar. 1985; accepted 29 Apr. 1985 tin, latamoxef and imipenem. The $\beta$-lactamases of these strains have been characterised with respect to the kinetics of antibiotic breakdown and the pattern of inhibition by various enzyme inhibitors.

\section{Materials and methods}

\section{Bacterial strains}

B. fragilis NCTC 9344, B. ovatus NCTC 11153, B. thetaiotaomicron NCTC 10582 and B. vulgatus NCTC 10583 were used as reference strains. B. fragilis 119 was isolated in this laboratory from a wound swab and identified by procedures recommended by Holdeman et al. (1977).

Other strains were kindly made available to us as follows: B. fragilis 2013E by I.N. Simpson (Glaxo Ltd, Greenford, Middlesex). B. distasonis R939 by J. Brazier (Luton Public Health Laboratory) and strains $B$. fragilis 0423 and B. thetaiotaomicron 0456 by V.L. Sutter (Wadsworth Veterans Administration Medical Center, Los Angeles, CA, USA).

\section{Antibiotics}

Solutions of benzylpenicillin (Glaxo Laboratories Ltd), clavulanic acid (Beecham Pharmaceuticals), cefoxitin (Merck Sharp and Dohme Ltd) and latamoxef (Eli Lilly and Co. Ltd) were freshly prepared as required in sterile distilled water. Appropriate concentrations of 
imipenem (Merck Sharp and Dohme Ltd) were freshly prepared in $0.01 \mathrm{M}$ phosphate buffer $(p \mathrm{H} \mathrm{7.0)}$ according to the manufacturers instructions.

\section{Culture medium}

Brain-heart-infusion broth supplemented with yeast extract $5 \mathrm{mg} / \mathrm{ml}$, haemin $5 \mu \mathrm{g} / \mathrm{ml}$ and menadione $1 \mu \mathrm{g} / \mathrm{ml}$ (BHIS), was used throughout. Agar $1.0 \%$ and lysed horse blood $5 \%$ were added for minimum inhibitory concentration (MIC) titrations. All culture media except those used for viable counting were pre-reduced by incubation overnight in a mixture of $\mathrm{N}_{2} 80 \%, \mathrm{CO}_{2} 10 \%, \mathrm{H}_{2} 10 \%$.

\section{Sensitivity tests}

MICs of antibiotics were determined by spot inoculation of $0.001 \mathrm{ml}$ of 1 in 10 and 1 in 1000 dilutions of overnight cultures in BHIS on to plates containing serial twofold dilutions of antibiotics; the lowest concentration that completely inhibited growth after incubation for $48 \mathrm{~h}$ was taken as the MIC.

\section{Turbidimetric studies}

Bacteria from overnight broth cultures were seeded into 9-ml volumes of prereduced BHIS to achieve an inoculum of $c .10^{6} \mathrm{cfu} / \mathrm{ml}$. Antibiotic was added either immediately after inoculation or when bacterial growth had raised the opacity of the cultures to $30 \%$ of that obtained with a fully grown broth culture. At this point the viable count was approximately $10^{8} \mathrm{cfu} / \mathrm{ml}$. The tubes were incubated anaerobically in a six-channel turbidimeter (O'Grady and Eley, 1983). In this system, antibiotic can be added during growth, or samples removed without disturbing anaerobiosis so that antibiotic-induced morphological changes can be observed and viable counting procedures performed. To detect antibiotic breakdown, cultures exposed to antibiotic overnight were centrifuged at $3000 \mathrm{rpm}$ for $20 \mathrm{~min}$. Supernates were removed and assayed by a well-diffusion technique (Eley and Greenwood, 1981).

\section{Viable counts}

Samples of broth cultures were removed during turbidimetry experiments and were diluted in fresh BHIS broth; further dilutions in BHIS agar were made with the Colworth 'Droplette' dispenser (A.J. Seward Ltd, London). Colonies in the agar droplets were counted with the illuminated magnifier and counter unit incorporated in the 'Droplette' device. Viable counts were expressed in terms of the mean number of $\mathrm{cfu} / \mathrm{ml}$.

\section{Preparation of crude $\beta$-lactamase}

The $\beta$-lactamase preparations were obtained from ultrasonicated bacteria as follows: surface growth from blood-agar cultures was scraped off into $4 \mathrm{ml}$ of $0.02 \mathrm{M}$ phosphate buffer $(p H$ 7.0) containing $1 \mathrm{~mm}$ dithiothreitol and the cells were disrupted with an ultrasonicator (MSE PG-100, MSE Scientific Instruments, Crawley, Sussex). Cell debris was removed by centrifugation at $5000 \mathrm{~g}$ for 30 min at $4^{\circ} \mathrm{C}$ (MSE 'Coolspin'). The clear supernates were stored at $-20^{\circ} \mathrm{C}$ until required.

Protein content of sonicates was estimated by the method of Lowry et al. (1951) with bovine serum albumin as the standard.

Isoelectric focusing of crude $\beta$-lactamase extracts was performed on cellulose acetate membranes according to the method previously described by Eley et al. (1983).

\section{Quantitation of $\beta$-lactamase and effect of inhibitors}

Enzyme activity and enzyme inhibition analyses were performed in a centrifugal fast analyser (Centrifichem 400, Union Carbide, Terrytown, New York) by following a colour change in the chromogenic cephalosporin,

Table I. Conditions used for high performance liquid chromatography

\begin{tabular}{|c|c|c|c|c|c|}
\hline Antibiotic & Mobile-phase & $\begin{array}{l}\text { Flow- } \\
\text { rate } \\
(\mathrm{ml} / \mathrm{min})\end{array}$ & $\begin{array}{l}\text { Injection } \\
\text { volume } \\
\quad(\mu \mathrm{l})\end{array}$ & $\begin{array}{l}\text { Wavelength } \\
(\mathrm{nm})\end{array}$ & $\begin{array}{l}\text { Sensitivity } \\
\text { (A.U.F.S.)* }\end{array}$ \\
\hline $\begin{array}{l}\text { Benzyl } \\
\text { penicillin }\end{array}$ & $\begin{array}{c}\mathrm{CH}_{3} \mathrm{CN}: 0.01 \mathrm{M} \text { Ammonium } \\
\text { acetate }\end{array}$ & 2 & 25 & 227 & 0.01 \\
\hline $\begin{array}{l}\text { Clavulanic } \\
\text { acid }\end{array}$ & $20: 80$ & & & & \\
\hline Imipenem & & 2 & 25 & 300 & $\begin{array}{l}0.08 \\
0.04\end{array}$ \\
\hline Cefoxitin & $\begin{array}{c}\mathrm{CH}_{3} \mathrm{CN}: 0.01 \mathrm{M} \text { Ammonium } \\
10: 90 \quad \text { acetate }\end{array}$ & 2 & 25 & 280 & 0.02 \\
\hline Latamoxef & $\begin{array}{c}\mathrm{H}_{2} \mathrm{O}: \mathrm{CH}_{3} \mathrm{OH}: \begin{array}{l}\text { o-phosphoric } \\
\text { acid }\end{array} \\
75: 24: 1\end{array}$ & 2 & 25 & 280 & 0.02 \\
\hline
\end{tabular}

* Absorbance unit full scale. 
nitrocefin, at $500 \mathrm{~nm}$. The total reaction volume was 300 $\mu \mathrm{l}$ which included $250 \mu \mathrm{l}$ of nitrocefin solution (to give a final concentration of $50 \mu \mathrm{g} / \mathrm{ml}$ ), $25 \mu \mathrm{l}$ of distilled water, $15 \mu \mathrm{l}$ of the enzyme preparation and $10 \mu \mathrm{l}$ of inhibitor. Assays were routinely performed at $37^{\circ} \mathrm{C}$ and the nitrocefin solution and enzyme + inhibitor mixture were temperature equilibrated for $15 \mathrm{~min}$ before mixing.

The inhibitors tested were para-chloromercuribenzoate (pcmb), cloxacillin, clavulanic acid, sulbactam, cefoxitin, latamoxef and imipenem at concentrations $(\mu \mathrm{M})$ of $0 \cdot 1,1,10$ and 100. Enzyme preparations from strains that produced high levels of $\beta$-lactamase were standardized to give relative activities similar to those of the type cultures by making appropriate dilutions with phosphate buffer. Appropriate enzyme and substrate controls were included with each experiment.

\section{High performance liquid chromatography (HPLC)}

The kinetics of breakdown of latamoxef, cefoxitin, imipenem and a combination of benzylpenicillin and clavulanic acid were determined by HPLC on a $100 \times 4$ mm diameter ODS-Hypersil $5 \mu$ column. The conditions used are shown in table I. Clavulanic acid was derivatised with imidazole by the method of Foulstone and Reading (1982) before injection on to the column. The kinetics of $\beta$-lactamase-mediated inactivation of the $\beta$-lactam antibiotics were determined as follows: crude $\beta$-lactamase extract $0.1 \mathrm{ml}$ and antibiotic solution $50 \mu \mathrm{g} / \mathrm{ml}$ were prewarmed at $37^{\circ} \mathrm{C}$ for $5 \mathrm{~min}$, mixed and incubated at $37^{\circ} \mathrm{C}$. Samples were removed for HPLC analysis at 0, 1, 2, 3, 4 and $22 \mathrm{~h}$. Antibiotic controls in which distilled water was substituted for $\beta$-lactamase extract were examined in parallel.

\section{Results}

\section{Minimum inhibitory concentrations}

MICs of cefoxitin, latamoxef, imipenem and benzylpenicillin (in the presence and absence of clavulanic acid) for the nine test strains are shown in table II. Type-culture strains of $B$. fragilis and $B$. vulgatus were more susceptible to cefoxitin, latamoxef and imipenem than were those of $B$. ovatus and $B$. thetaiotaomicron. The presence of clavulanic acid $4 \mu \mathrm{g} / \mathrm{ml}$ (a concentration which alone had no inhibitory effect) reduced the MIC of benzylpenicillin for these four strains from $16-32 \mu \mathrm{g} / \mathrm{ml}$ to $0 \cdot 25-$ $0.5 \mu \mathrm{g} / \mathrm{ml}$. The other five strains had raised MICs in titrations of all the test compounds; an exception was $B$. fragilis 2013E, which was as sensitive as the type-culture $B$. fragilis strain to the combination of benzylpenicillin and clavulanic acid.

\section{Turbidimetric experiments}

The response of all the test strains to antibiotics was observed by continuous turbidimetric monitoring. Antibiotic was added at the same time as an inoculum of $c .10^{6} \mathrm{cfu} / \mathrm{ml}$, or when bacterial growth had raised the inoculum to $c .10^{8} \mathrm{cfu} / \mathrm{ml}$. The forms of response obtained are illustrated in fig. 1, which shows the results of exposure of the four $B$. fragilis strains to latamoxef in experiments with the smaller inoculum. Growth of $B$. fragilis NCTC 9344 was slightly inhibited by latamoxef $0.06 \mu \mathrm{g} / \mathrm{ml}$ (the

Table II. Susceptibilities of the test strains to selected $\beta$-lactam antibiotics

\begin{tabular}{|c|c|c|c|c|c|}
\hline \multirow[b]{2}{*}{ Bacterial strain } & \multicolumn{5}{|c|}{ Minimum inhibitory concentration* $(\mu \mathrm{g} / \mathrm{ml})$} \\
\hline & cefoxitin & latamoxef & imipenem & $\begin{array}{c}\text { benzyl } \\
\text { penicillin }\end{array}$ & $\begin{array}{c}\text { benzylpenicillin } \\
+ \\
\text { clavulanic acid } \\
(4 \mu \mathrm{g} / \mathrm{ml})\end{array}$ \\
\hline $\begin{array}{l}\text { B. fragilis } \\
\text { NCTC } 9344\end{array}$ & 8 & $0 \cdot 25$ & $0 \cdot 12$ & 16 & $0 \cdot 25$ \\
\hline $\begin{array}{l}\text { B. vulgatus } \\
\text { NCTC } 10583\end{array}$ & 8 & $0 \cdot 25$ & $0 \cdot 12$ & 16 & $0 \cdot 5$ \\
\hline $\begin{array}{l}\text { B. ovatus } \\
\text { NCTC } 11153\end{array}$ & 64 & 8 & 1 & 32 & $0 \cdot 5$ \\
\hline $\begin{array}{l}\text { B. thetaiotaomicron } \\
\text { NCTC } 10582\end{array}$ & 32 & 2 & 0.5 & 32 & 0.5 \\
\hline B. fragilis $2013 \mathrm{E}$ & 16 & 8 & 2 & $>64$ & $0 \cdot 25$ \\
\hline B. fragilis 0423 & 32 & $>64$ & 2 & $>64$ & 1 \\
\hline $\begin{array}{l}\text { B. thetaiotaomicron } \\
0456\end{array}$ & $>64$ & $>64$ & 8 & $>64$ & 4 \\
\hline B. distasonis R939 & 32 & $>64$ & 2 & $>64$ & $>8$ \\
\hline B. fragilis 119 & 64 & $>64$ & 32 & $>64$ & $>8$ \\
\hline
\end{tabular}

* Inoculum of $10^{5} \mathrm{cfu}$ per spot. 

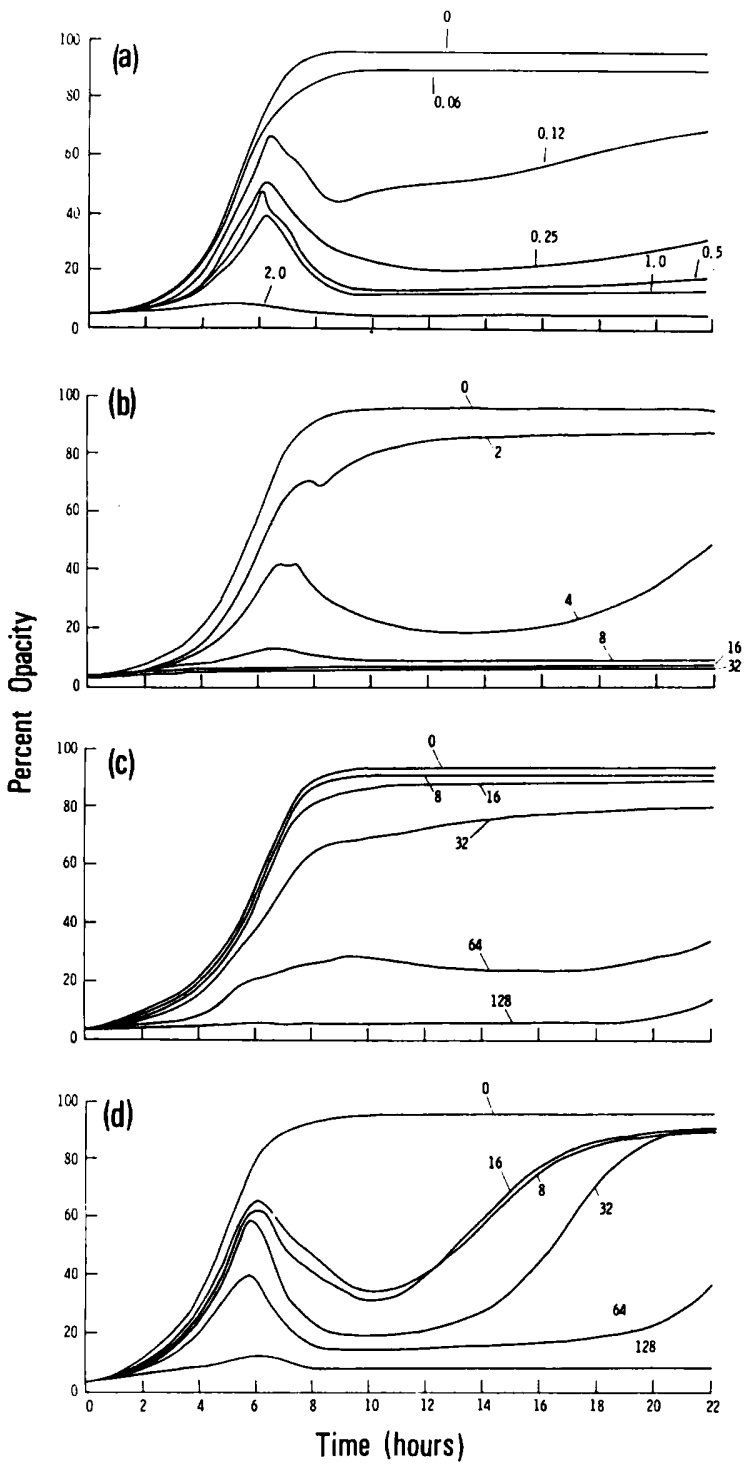

Fig. 1. Continuous opacity records of (a) B. fragilis NCTC 9344, (b) B. fragilis 2013E, (c) B. fragilis 0423 and (d) B. fragilis 119 exposed to latamoxef at the concentrations $(\mu \mathrm{g} / \mathrm{ml})$ shown. The inoculum was $c .10^{6} \mathrm{cfu} / \mathrm{ml}$ in each case.

minimum antibacterial concentration; MAC) but the concentration inhibiting growth completely during overnight incubation (corresponding to the conventionally determined broth MIC) was $2 \mu \mathrm{g} / \mathrm{ml}$ (fig. 1a). Bioassay of broth supernates at the end of the experiment revealed no loss of activity of latamoxef. $B$. fragilis $2013 \mathrm{E}$ was much more resistant than the type-culture strain in terms of both MAC and MIC (fig. 1b) but again, no degradation of latamoxef was revealed by bioassay. MAC and MIC values for $B$. fragilis 0423 were even higher (fig. 1c); with this strain, complete degradation of latamoxef was observed at concentrations below 64 $\mu \mathrm{g} / \mathrm{ml}$. B. fragilis 119 responded partially to latamoxef $2 \mu \mathrm{g} / \mathrm{ml}$, but the MIC, estimated turbidimetrically, was $128 \mu \mathrm{g} / \mathrm{ml}$ (fig. 1d); intermediate concentrations produced an initial response to the antibiotic, followed by resumption of growth, which was accompanied by complete loss of lata- moxef activity.

A summary of the turbidimetric results obtained with all the strains and antibiotics, showing MAC, MIC and antibiotic degradation data for the two inocula, is shown in table III.

\section{Viable counts}

Sequential viable counts were performed during the course of all turbidimetric experiments in which the larger $\left(10^{8} \mathrm{cfu}\right)$ inoculum was used. The results are summarised in table IV. Although the antibiotic concentration achieving a bactericidal effect (defined as $99 \%$ killing after $3 \mathrm{~h}$ and $99.9 \%$ killing after $24 \mathrm{~h}$ ) varied considerably from strain to strain and from compound to compound, imipenem was always the most bactericidal agent. With some strains, latamoxef and cefoxitin did not achieve a bactericidal effect at clinically attainable concentrations.

\section{Activity of $\beta$-lactamase extracts}

Crude extracts obtained by ultrasonication of bacterial suspensions were assayed for $\beta$-lactamase activity spectrophotometrically with nitrocefin as substrate. The amount of protein in the extracts was determined and the specific activity of the $\beta$ lactamases calculated. The results are shown in table V. Specific activity of extracts of the typeculture strains (calculated as $\mu \mathrm{M}$ of nitrocefin degraded $/ \mathrm{min} / \mathrm{mg}$ of protein) ranged from 0.014 to $0 \cdot 075$. Values for the specific activities of the resistant strains were 3-300 times higher.

\section{Isoelectric focusing}

Isoelectric points $(\mathrm{pI})$ of the crude $\beta$-lactamase extracts are also shown in table $V$. The type-culture strains and those resistant strains that exhibited relatively low $\beta$-lactamase specific activity ( $B$. distasonis R939 and $B$. fragilis 119 ) yielded a single $\mathrm{pI}$ value on isoelectric focusing, although the value varied considerably from strain to strain. $B$. fragilis 0423 gave two distinct bands on isoelectric focusing while B. fragilis 2013E and B. thetaiotaomicron 0456 yielded four bands each. 
Table III. A summary of the turbidimetric results obtained with all the strains and antibiotics

\begin{tabular}{|c|c|c|c|c|c|c|c|c|c|c|c|c|c|}
\hline \multirow[b]{2}{*}{ Bacterial strain } & \multirow{2}{*}{$\begin{array}{l}\text { Inoculum } \\
(\mathrm{cfu} / \mathrm{ml})\end{array}$} & \multicolumn{3}{|c|}{ cefoxitin } & \multicolumn{3}{|c|}{ latamoxef } & \multicolumn{3}{|c|}{ imipenem } & \multicolumn{3}{|c|}{$\begin{array}{c}\text { benzylpenicillin } \\
+ \\
\text { clavulanic acid } \\
4 \mu \mathrm{g} / \mathrm{ml}\end{array}$} \\
\hline & & MAC & MIC & B'down & MAC & MIC & B'down & MAC & MIC & B'down & MAC & MIC & B'down \\
\hline B. fragilis & $10^{6}$ & 4 & 8 & - & $0 \cdot 12$ & 2 & - & 0.03 & 0.5 & - & 0.06 & 0.5 & - \\
\hline NCTC 9344 & $10^{8}$ & 4 & 16 & - & 2 & 4 & - & 0.25 & 1 & - & $0 \cdot 5$ & 4 & - \\
\hline B. vulgatus & $10^{6}$ & $0 \cdot 5$ & 2 & - & $0 \cdot 12$ & 2 & - & $0 \cdot 12$ & 0.5 & - & $0 \cdot 06$ & $0 \cdot 25$ & - \\
\hline NCTC 10583 & $10^{8}$ & 1 & 4 & - & 1 & 4 & - & $0 \cdot 25$ & 2 & - & $0 \cdot 5$ & 2 & - \\
\hline B. ovatus & $10^{6}$ & 16 & 32 & - & 16 & 128 & - & $0 \cdot 12$ & $0 \cdot 25$ & - & $0 \cdot 25$ & $0 \cdot 5$ & - \\
\hline NCTC 11153 & $10^{8}$ & 16 & 32 & - & 64 & $>128$ & - & $0 \cdot 25$ & 1 & - & $0 \cdot 5$ & 1 & - \\
\hline B. thetaiotaomicron & $10^{6}$ & 16 & 32 & - & 8 & $>128$ & - & $0 \cdot 06$ & 1 & - & $0 \cdot 25$ & 2 & - \\
\hline NCTC 10582 & $10^{8}$ & 32 & 128 & - & $>128$ & $>128$ & - & 0.5 & 4 & - & 2 & 8 & - \\
\hline B. fragilis & $10^{6}$ & 4 & 8 & - & 2 & 8 & - & 0.06 & 0.5 & - & 0.06 & 1 & - \\
\hline $2013 \mathrm{E}$ & $10^{8}$ & 4 & 16 & - & 4 & 16 & - & $0 \cdot 12$ & 0.5 & - & $0 \cdot 5$ & 4 & + \\
\hline B. fragilis & $10^{6}$ & 4 & 32 & + & 32 & 128 & + & $0 \cdot 06$ & $0 \cdot 5$ & - & $0 \cdot 12$ & 1 & - \\
\hline 0423 & $10^{8}$ & 16 & 64 & + & 64 & 128 & + & $0 \cdot 25$ & $0 \cdot 5$ & - & 2 & 16 & + \\
\hline B. thetaiotaomicron & $10^{6}$ & 64 & 128 & + & $>128$ & $>128$ & + & $0 \cdot 5$ & 2 & - & 4 & 8 & + \\
\hline 0456 & $10^{8}$ & 128 & $>128$ & + & $>128$ & $>128$ & + & $0 \cdot 5$ & 4 & - & 4 & $>128$ & + \\
\hline B. distasonis & $10^{6}$ & 16 & 32 & + & 64 & $>128$ & + & $0 \cdot 25$ & 1 & - & 8 & 16 & + \\
\hline R939 & $10^{8}$ & 32 & 128 & + & 128 & $>128$ & + & 2 & 4 & - & 16 & 32 & + \\
\hline B. fragilis & $10^{6}$ & 8 & 32 & + & 2 & 128 & + & $0 \cdot 25$ & 16 & + & 4 & 128 & + \\
\hline 119 & $10^{8}$ & 16 & 128 & + & 128 & $>128$ & + & 32 & $>128$ & + & 64 & $>128$ & + \\
\hline
\end{tabular}

$\mathrm{MAC}=$ Minimum antibacterial concentration, the lowest concentration needed to produce an observable antibacterial effect; B'down = antibiotic breakdown after overnight incubation in broth culture.

Table IV. Comparative bactericidal activity of antibiotics against the test strains

\begin{tabular}{|c|c|c|c|c|c|c|c|c|}
\hline \multirow[b]{3}{*}{ Bacterial strain } & \multicolumn{8}{|c|}{$\begin{array}{c}\text { Concentration ( } \mu \mathrm{g} / \mathrm{ml}) \text { causing bactericidal effect at } \\
\text { the time indicated }{ }^{*}\end{array}$} \\
\hline & \multicolumn{2}{|c|}{ cefoxitin } & \multicolumn{2}{|c|}{ latamoxef } & \multicolumn{2}{|c|}{ imipenem } & \multicolumn{2}{|c|}{$\begin{array}{c}\text { benzylpenicillin } \\
+ \\
\text { clavulanic acid } \\
4 \mu \mathrm{g} / \mathrm{ml}\end{array}$} \\
\hline & $3 \mathrm{~h}$ & $24 \mathrm{~h}$ & $3 \mathrm{~h}$ & $24 \mathrm{~h}$ & $3 \mathrm{~h}$ & $24 \mathrm{~h}$ & $3 \mathrm{~h}$ & $24 \mathrm{~h}$ \\
\hline $\begin{array}{l}\text { B. fragilis } \\
\text { NCTC } 9344\end{array}$ & 16 & 16 & 8 & 4 & 0.5 & 0.5 & 0.5 & 0.5 \\
\hline $\begin{array}{l}\text { B. vulgatus } \\
\text { NCTC } 10583\end{array}$ & 8 & 8 & 8 & 4 & 2 & 1 & 2 & 4 \\
\hline $\begin{array}{l}\text { B. ovatus } \\
\text { NCTC } 11153\end{array}$ & 64 & 16 & $>128$ & $>128$ & 0.5 & $0 \cdot 25$ & 1 & $0 \cdot 5$ \\
\hline $\begin{array}{l}\text { B. thetaiotaomicron } \\
\text { NCTC } 10582\end{array}$ & $>128$ & 32 & $>128$ & $>128$ & 4 & 0.5 & 8 & 1 \\
\hline B. fragilis $2013 \mathrm{E}$ & 16 & 32 & 16 & 8 & $0 \cdot 25$ & 0.25 & 2 & 2 \\
\hline B. fragilis 0423 & 32 & 64 & 16 & 128 & $0 \cdot 25$ & 0.5 & 2 & 0.5 \\
\hline $\begin{array}{l}\text { B. thetaiotaomicron } \\
0456\end{array}$ & $>128$ & $>128$ & $>128$ & $>128$ & 32 & 2 & $>128$ & 128 \\
\hline B. distasonis R939 & 128 & 64 & $>128$ & $>128$ & 4 & 2 & 64 & 32 \\
\hline B. fragilis 119 & 64 & 128 & $>128$ & $>128$ & 32 & 32 & $>128$ & 64 \\
\hline
\end{tabular}

* Bactericidal effect defined as $99 \%$ killing after $3 \mathrm{~h} ; 99.9 \%$ killing after $24 \mathrm{~h}$. 
Table V. Specific activities and isoelectric points of $\beta$-lactamases produced by the test strains

\begin{tabular}{|c|c|c|}
\hline Bacterial strain & $\begin{array}{l}\text { Specific* } \\
\text { activity }\end{array}$ & $\mathrm{pI} \dagger$ \\
\hline $\begin{array}{l}\text { B. fragilis } \\
\text { NCTC } 9344\end{array}$ & 0.031 & $5 \cdot 1$ \\
\hline $\begin{array}{l}\text { B. vulgatus } \\
\text { NCTC } 10583\end{array}$ & 0.014 & $4 \cdot 9$ \\
\hline $\begin{array}{l}\text { B. ovatus } \\
\text { NCTC } 11153\end{array}$ & 0.075 & $6 \cdot 3$ \\
\hline $\begin{array}{l}\text { B. thetaiotaomicron } \\
\text { NCTC } 10582\end{array}$ & $0 \cdot 042$ & $4 \cdot 4$ \\
\hline B. fragilis $2013 \mathrm{E}$ & $2 \cdot 731$ & $\begin{array}{l}5 \cdot 0,5 \cdot 1 \\
5 \cdot 2,5 \cdot 3\end{array}$ \\
\hline B. fragilis 0423 & $1 \cdot 380$ & $4 \cdot 6,5 \cdot 0$ \\
\hline $\begin{array}{l}\text { B. thetaiotaomicron } \\
0456\end{array}$ & $3 \cdot 594$ & $\begin{array}{l}3 \cdot 7,4 \cdot 1 \\
4 \cdot 6,5 \cdot 1\end{array}$ \\
\hline B. distasonis R939 & 0.467 & $4 \cdot 5$ \\
\hline B. fragilis 119 & $0 \cdot 245$ & $4 \cdot 6$ \\
\hline
\end{tabular}

* Nitrocefin degradation measured as $\mu \mathrm{M} /$ $\mathrm{min} / \mathrm{mg}$ of protein.

$\dagger$ For strains showing more than one pI value by isoelectric focusing the major band is in bold.

\section{Inhibition profiles}

The effect of various $\beta$-lactamase inhibitors on the degradation of nitrocefin by crude extracts of the nine Bacteroides strains was investigated by centrifugal analysis in the Centrifichem system. The results are shown in table VI. Inhibitor profiles were not useful in discriminating between enzymes produced by the type-culture strains, except that the $B$. vulgatus enzyme appeared to be somewhat refractory to inhibition by sulbactam. However, the enzymes produced by the more resistant Bacteroides strains each displayed a characteristic inhibitor profile (table VI). The enzyme most susceptible to inhibition was that produced by $B$. fragilis $2013 \mathrm{E}$; in marked contrast, the enzyme of $B$. fragilis 119 was inhibited weakly by pcmb and not at all by any of the other inhibitors tested.

\section{Degradation of antibiotics by $\beta$-lactamases of the resistant Bacteroides strains}

The kinetics of breakdown of cefoxitin, latamoxef, imipenem and benzylpenicillin (in the presence of clavulanic acid) by crude extracts of the five resistant Bacteroides strains were followed by HPLC analysis of sequential samples. The enzyme from $B$. fragilis 2013E caused no detectable breakdown of any of the agents tested; results for the other four strains are shown in fig. 2. Crude extracts of all four strains degraded cefoxitin and latamoxef partially during overnight incubation; enzymes from $B$. thetaiotaomicron 0456 and B. fragilis 119 degraded latamoxef more rapidly than cefoxitin (fig. $2 a$ and $2 b$ ) and all the enzymes rapidly degraded benzylpenicillin in the presence of clavulanic acid (fig. 2d). Imipenem was stable to all the enzymes, except that produced by B. fragilis 119 , which completely degraded the antibiotic within 90 min (fig. 2c).

Table VI. Inhibitor profiles obtained by Centrifichem analysis

\begin{tabular}{|c|c|c|c|c|c|c|c|}
\hline \multirow[b]{2}{*}{ Bacterial strain } & \multicolumn{7}{|c|}{$\operatorname{IC50}(\mu \mathrm{M})$} \\
\hline & pcmb & imipenem & latamoxef & cefoxitin & $\begin{array}{l}\text { clavulanic } \\
\text { acid }\end{array}$ & sulbactam & cloxacillin \\
\hline $\begin{array}{l}\text { B. fragilis } \\
\text { (NCTC 9344) }\end{array}$ & 100 & $<0.1$ & $<0.1$ & $<0.1$ & $<0.1$ & $<0.1$ & 10 \\
\hline $\begin{array}{l}\text { B. vulgatus } \\
\text { (NCTC 10583) }\end{array}$ & 100 & $<0.1$ & $<0 \cdot 1$ & $<0.1$ & $<0.1$ & 10 & 10 \\
\hline $\begin{array}{l}\text { B. ovatus } \\
\text { (NCTC 11153) }\end{array}$ & 100 & $<0 \cdot 1$ & $<0 \cdot 1$ & $<0.1$ & $<0.1$ & $<0 \cdot 1$ & 10 \\
\hline $\begin{array}{l}\text { B. thetaiotaomicron } \\
\text { (NCTC 10582) }\end{array}$ & 100 & $<0 \cdot 1$ & $<0 \cdot 1$ & $<0.1$ & $<0 \cdot 1$ & $<0 \cdot 1$ & 10 \\
\hline B. fragilis $2013 \mathrm{E}$ & 100 & $<0.1$ & $<0.1$ & $<0.1$ & $<0.1$ & $<0.1$ & 100 \\
\hline B. fragilis 0423 & $>100$ & $<0.1$ & 10 & 1 & $<0.1$ & 1 & $>100$ \\
\hline $\begin{array}{l}\text { B. thetaiotaomicron } \\
0456\end{array}$ & $>100$ & $<0 \cdot 1$ & 100 & 1 & 1 & 10 & $>100$ \\
\hline B. distasonis R939 & $>100$ & $<0 \cdot 1$ & 10 & 1 & 1 & 1 & $>100$ \\
\hline B. fragilis 119 & 100 & $>100$ & $>100$ & $>100$ & $>100$ & $>100$ & $>100$ \\
\hline
\end{tabular}

IC50 = lowest concentration of inhibitor producing $\geqslant 50 \%$ inhibition. 


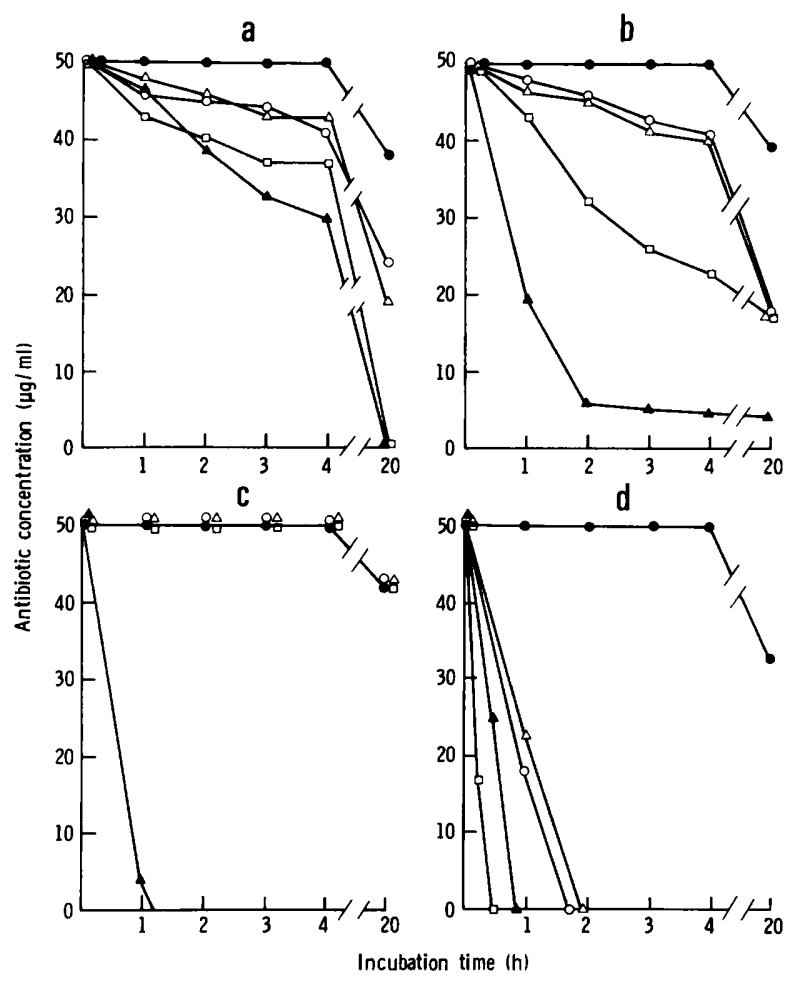

Fig. 2. $\beta$-lactamase-mediated degradation kinetics of (a) cefoxitin, (b) latamoxef, (c) imipenem and (d) benzylpenicillin in the presence of clavulanic acid $4 \mu \mathrm{g} / \mathrm{ml}$; all measurements were by HPLC; $\bullet=$ control; $\Delta=B$. fragilis $0423 ; 0=B$. distasonis $\mathrm{R} 939 ; \square=B$. thetaiotaomicron $0456 ; \Delta=B$. fragilis 119 .

\section{Discussion}

Virtually all members of the $B$. fragilis group produce $\beta$-lactamases, the genetic information for which is probably chromosomally located (Nord and Olsson-Liljequist, 1981). These enzymes generally inactivate cephalosporins (but not cefoxitin) more rapidly than penicillins (Olsson et al., 1976). Inactivation can be prevented by clavulanic acid (Timewell et al., 1981). Furthermore, strains of Bacteroides are occasionally encountered that produce increased amounts of $\beta$-lactamase and this usually correlates with a decrease in susceptibility (Simpson et al., 1982). In the present study, typeculture strains of four species within the $B$. fragilis group and selected strains producing enhanced levels of $\beta$-lactamase were investigated.

In MIC titrations, the order of activity of the antibiotics tested against the type-culture strains was imipenem $>$ the combination of benzylpenicillin and clavulanic acid $>$ latamoxef $>$ cefoxitin. The superiority of imipenem and the penicillin-clavula- nic acid combination was also observed in tests of bactericidal (reduction in viable count) and bacteriolytic (reduction in opacity) activity. As reported earlier, (Eley and Greenwood, 1984) B. fragilis and $B$. vulgatus appeared more susceptible than $B$. ovatus and $B$. thetaiotaomicron and the difference in activity between latamoxef and cefoxitin seen in MIC titrations, was much less marked when judged in bactericidal and bacteriolytic terms.

Among strains selected on the basis of increased levels of $\beta$-lactamase production, the generally superior activity of imipenem and penicillin-clavulanic acid was maintained, although two strains displayed much reduced susceptibility to penicillinclavulanic acid and one, B. fragilis 119 (a clinical isolate from an infected wound), was resistant to imipenem. Imipenem-resistant strains are uncommon, but have been reported previously (Tally and Jacobus, 1983; Yotsuji et al., 1983).

Investigation of the $\beta$-lactamases of the test strains showed that the enzymes of the type-culture species exhibited low specific activity and widely 
different $\mathrm{pI}$ values on isoelectric focusing. The enzymes were very susceptible to a wide range of $\beta$ lactamase inhibitors, although pcmb was less active than the other inhibitors tested. The $B$. vulgatus enzyme was relatively resistant to inhibition by sulbactam. Similar inhibition profiles have been reported by Tajima et al., (1983).

Strains producing elevated levels of $\beta$-lactamase displayed a wide variety of properties: the specific activities varied greatly from three to 300 times those of the type-culture strains. Curiously, $B$. fragilis 119, which was the most resistant strain tested in MIC titrations, exhibited the lowest specific activity among the group of resistant strains. The enzyme produced by this strain was able to inactivate imipenem, latamoxef and, more slowly, cefoxitin and was more resistant than any other $\beta$ lactamase tested to inhibition by a variety of $\beta$ lactam compounds. This enzyme also had a pI value that was unusual in $B$. fragilis. In marked contrast, the enzyme produced by $B$. fragilis $2013 \mathrm{E}$ was unable to inactivate latamoxef, cefoxitin or imipenem; the inhibition profile was similar to that of $B$. fragilis NCTC 9344, and although several bands were resolved by isoelectric focusing, the pI values were close to that of the enzyme from the typeculture strain. It seems likely that $B$. fragilis $2013 \mathrm{E}$ produces an elevated level of the normal chromosomal $\beta$-lactamase of $B$. fragilis.

Enzymes from the remaining $\beta$-lactamase highproducing strains all inactivated latamoxef, cefoxitin and penicillin (in the presence of clavulanic acid) at a similar rate; they had characteristic $\mathrm{pI}$ bands on isoelectric focusing, including a possibly common band with a pI of 4.5-4.6, and displayed similar, but not identical inhibition profiles. The explanation for the apparent anomaly in which clavulanic acid was

\section{REFERENCES}

Anderson J D, Sykes R B 1973 Characterisation of a $\beta$-lactamase obtained from a strain of Bacteroides fragilis resistant to $\beta$ lactam antibiotics. Journal of Medical Microbiology 6:201206.

Cuchural G J, Tally F P, Jacobus N V, Marsh P K, Mayhew J W 1983 Cefoxitin inactivation by Bacteroides fragilis. Antimicrobial Agents and Chemotherapy 24:936-940.

Eley A, Greenwood D 1981 In-vitro activity of ceftizoxime against Bacteroides fragilis: comparison with benzylpenicillin, cephalothin and cefoxitin. Antimicrobial Agents and Chemotherapy 20:332-335.

Eley A, Ambler J, Greenwood D 1983 Isoelectric focusing of $\beta$ lactamases on cellulose acetate membranes. Journal of Antimicrobial Chemotherapy 12:193-196.

Eley A, Greenwood D 1984 Variations in susceptibility to latamoxef (moxalactam) and cefoxitin within the Bacteroides fragilis group. Journal of Antimicrobial Chemotherapy 13:245-255. able to inhibit these enzymes, yet failed to protect benzylpenicillin, probably lies in the amount of enzyme involved: for inhibitor studies, crude extracts were diluted to achieve similar rates of inactivation of nitrocefin, whereas undiluted extracts were used in the HPLC studies of antibiotic breakdown. Moreover, the time scale of the inhibitor studies ( $5 \mathrm{~min}$ ) was much shorter than that of the stability experiments.

Although all the strains examined in this study may produce different $\beta$-lactamases as judged by specific activity and isolelectric point, three broad patterns of response can be discerned. (i) Strains fully susceptible to latamoxef, cefoxitin and imipenem; the $\beta$-lactamases involved have low specific activity and broad susceptibility to enzyme inhibitors, including clavulanic acid, which can protect benzylpenicillin. The type-culture strains all conform to this pattern and B. fragilis $2013 \mathrm{E}$ is probably a high producer of the $B$. fragilis enzyme. (ii) Strains which are resistant to, and slowly inactivate, latamoxef and cefoxitin. They are more resistant than the type-culture strains to imipenem, but do not inactivate it. The enzymes involved are inhibited by imipenem and (somewhat less efficiently) by latamoxef, cefoxitin, clavulanic acid and sulbactam. B. fragilis $0423, B$. thetaiotaomicron 0456 and $B$. distasonis $\mathrm{R} 939$ belong to this group. (iii) Strains, represented in this study by $B$. fragilis 119 , that rapidly inactivate imipenem, latamoxef and (more slowly) cefoxitin. The enzyme is inhibited poorly by pcmb and not at all by other enzyme inhibitors. Since the present investigation was completed we have isolated two further imipenemresistant $B$. fragilis strains with identical enzyme characteristics.

Foulstone M, Reading C 1982 Assay of amoxycillin and clavulanic acid, the components of augmentin in biological fluids with high-performance liquid chromatography. Antimicrobial Agents and Chemotherapy 22:753-762.

Holdeman L V, Cato E P, Moore W E C 1977 Anaerobe laboratory manual, 4th edn. Virginia Polytechnic Institute and State University, Blacksburg, VA.

Lowry O H, Rosebrough N J, Farr A L, Randall R J 1951 Protein measurement with the Folin phenol reagent. Journal of Biological Chemistry 193:265-275.

Nord C E, Olsson-Liljequist B 1981 Resistance to $\beta$-lactam antibiotics in Bacteroides species. Journal of Antimicrobial Chemotherapy 8 Suppl D:33-42.

O'Grady F, Eley A 1983 Continuous opacity monitoring of the growth of bacteria under strict anaerobic conditions. Journal of Clinical Pathology 36:1229-32.

Olsson B, Nord C E, Wadström T 1976 Formation of Betalactamase in Bacteroides fragilis: cell-bound and extracellular activity. Antimicrobial Agents and Chemotherapy 9:727735. 
Sato K, Matsuura Y, Inoue M, Mitsuhashi S 1982 Properties of a new penicillinase type produced by Bacteroides fragilis. Antimicrobial Agents and Chemotherapy 22:579-584.

Simpson I N, Page C D, Harper P B 1982 The contribution of $\beta$ lactamases to $\beta$-lactam resistance in Bacteroides fragilis. Journal of Antimicrobial Chemotherapy 9:29-45.

Tajima M, Sawa K, Watanabe K, Ueno K 1983 The $\beta$ lactamases of genus Bacteroides. Journal of Antibiotics 36:423-428.
Tally F P, Jacobus N V 1983 Susceptibility of anaerobic bacteria to imipenem. Journal of Antimicrobial Chemotherapy 12:Suppl D, 47-51.

Timewell R, Taylor E, Phillips I 1981 The $\beta$-lactamases of Bacteroides species. Journal of Antimicrobial Chemotherapy 7:137-146.

Yotsuji A, Minami S, Inoue M, Mitsuhashi S 1983 Properties of novel $\beta$-lactamase produced by Bacteroides fragilis. Antimicrobial Agents and Chemotherapy 24:925-929. 